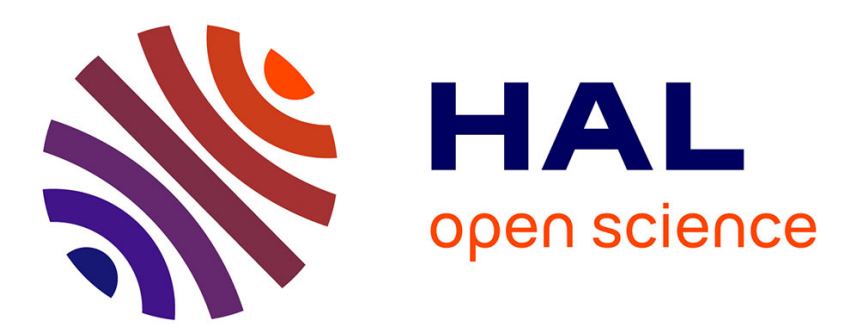

\title{
Links between knowledge and work and appropriate employment
}

\author{
Jake Murdoch, Jean-Jacques Paul
}

\section{To cite this version:}

Jake Murdoch, Jean-Jacques Paul. Links between knowledge and work and appropriate employment. Ulrich Teichler. Careers of University Graduates: Views and Experiences in Comparative Perspectives, Netherlands: Springer, pp.143-158, 2007, Higher Education Dynamics Volume 17. halshs00181325

\section{HAL Id: halshs-00181325 https://shs.hal.science/halshs-00181325}

Submitted on 19 Mar 2019

HAL is a multi-disciplinary open access archive for the deposit and dissemination of scientific research documents, whether they are published or not. The documents may come from teaching and research institutions in France or abroad, or from public or private research centers.
L'archive ouverte pluridisciplinaire HAL, est destinée au dépôt et à la diffusion de documents scientifiques de niveau recherche, publiés ou non, émanant des établissements d'enseignement et de recherche français ou étrangers, des laboratoires publics ou privés. 


\title{
LINKS BETWEEN KNOWLEDGE AND WORK AND APPROPRIATENESS OF EMPLOYMENT
}

\author{
Murdoch J. et Paul J-J. (2007), "Links Between Knowledge and Work and Appropriateness Of \\ Education", in U.Teichler, (dir.), Careers of University Graduates: Views and Experiences in \\ Comparative Perspectives, Springer Publishers, pp. 143-158
}

\section{INTRODUCTION}

As already discussed in previous chapters, the CHEERS graduate survey addressed the careers of graduates with respect to a broad range of dimensions. It did not only employ “objective” measures, i.e. facts which the respondents can report without major interpretative involvement: among others the duration up to first normal employment, the employment status, part-time versus full-time employment, and the gross annual income. The CHEERS questionnaire also asked the graduates to valuate and interpret their employment and work situation in several respects, where "objective" measures did not suffice.

Collecting a combination of factual information and respondents' rating has become customary in research on employment and work. This holds true, for example for many projects undertaken by the Research Centre for Education and the Labour Market (ROA), in Maastricht, the Netherlands, which is leading in this field and participated in the CHEERS survey (Allen et al. 2001). This can be observed as well in previous research projects undertaken by members of the CHEERS team in Austria (Kellermann 1996), Germany (Schomburg and Teichler 1993), Norway (Arnesen 2000) and the United Kingdom (Brennan and McGeever 1988; Brennan 1993).

In the latter domain graduates, first, were asked to characterize their employment and work within the framework of categories, which are often employed with regards to employees across economic sectors, areas of occupation and position as well as educational levels. Respondents were asked to state what they consider as a good job and about the extent to which this applies to their job - questions deriving from a tradition of research on "job satisfaction".

Second, the CHEERS survey tried to establish the graduates' views about the extent they consider their employment and work appropriate for a graduate. Research approaches of that kind emerged in 1970 s in the wake of the rapid expansion of higher education and the subsequent increase of the quota of graduates from institutions of higher education among new entrants in the labour force. It became obvious at that time that an analysis of the graduates' whereabouts according to occupational group did not suffice anymore to establish, whether graduates are "over-educated" and "under-employed" or whether a job, though not being considered typical for graduates according to yardstick previously common when the proprotion of graduates was relatively small, could be considered "appropriate". It could well be that jobs not linked to a high salary and to a privileged position actually were demanding as far as the level of job tasks and job requirements is concerned. Also, it did not seem to suffice anymore to establish whether graduates from certain fields of study end up in certain professions or sectors of employment in order to establish whether the allocation has work in linking competencies with respective work tasks. It could well be that a graduate could use the knowledge acquired in the course of study well or could consider his or her course of study a good preparation for the subsequent work, if the traditional notions of links between fields of study and occupational areas did not suggest that.

A summary of the first generation of research on graduate employment and work addressing the links between substance of knowledge and work and the appropriateness of employment according to the graduates' perception came to conclusion the researchers have chosen so heterogeneous measures that the findings were more revealing as regards the researchers' concepts than regarding the real situation of graduate employment and work (Teichler 1988). Up to the present, no widespread consensus emerged as the regads the most appropriate means of measuring the extent to which study and work both regarding the level education and employment and the substance of knowledge and work tasks. And surveys employing a broad range of measures did not come to the conclusion that certain individual measures could be viewed as covering the issues involved sufficiently (see Teichler and Buttgereit, 1992).

We decided, therefore, to characterize these relationships in various ways: the extent to which their field of study matches the area of work, the extent to which they use on the job the knowledge acquired 
in the course of study, what level of course programme and degree was most appropriate for their employment and work as compared to the level of degree their were awarded. Moreover, we asked the graduates to rate the appropriatness of their level of education generally, thereby taking into account all dimensions of their employment and work (status, position, income, work tasks etc.). Finally, they were asked to state the extent which their work situation at the time the survey was conducted actually meets the expectation they have had at the time they started their study.

\section{FREQUENCY OF MARGINAL UTILISATION OF KNOWLEDGE AND INAPPROPRIATE EMPLOYMENT}

The first question addresses exclusively the substantive link between study and work. As Table 1 shows, altogether 21 percent of the graduates see only little or no use at all on job of the knowledge and skills they had acquired in their course of study.

In the second question, graduates are asked to characterise the relationships between their field of study their area of work both with respect to the level and the substance. With respect to the level of education and employment, 8 percent of the graduates, as Table 2 indicates, do not see their area of work requiring higher education study and a degree at all. A further 9 percent perceive a mismatch between the field of study and the area of work.

In the third question, graduates were asked to state the most appropriate level of education for their employment and work. Again, as shown in Table 3, 8 percent consider a higher education degree as superfluous for their employment and work.

A further 12 percent (thus altogether 20\%) seem to conceive themselves “overeducated”, because they consider a lower level of higher education or tertiary education more appropriate for their job than the level they actually had reached. In contrast, 12 percent believe that a higher level than the one they had reached was most appropriate for their actual employment and work.

In the fourth question, graduates were encouraged to rate the appropriateness between their level of education and their employment and work by taking all relevant dimensions into account both with respect to the level and the substance of education and work. Table 4 shows that 13 percent of the graduates consider their employment and work as predominantly or completely inappropriate to their level of education.

Altogether we note that, depending on the measure employed, between 8 percent and 21 percent of the graduates surveyed perceived a marginal or no link between study and subsequent employment and work. This cannot be viewed as a high rate if compared to that noted on the basis of employment statistics. The findings of our study, indeed, confirm that a noteworthy proportion of graduates ending up in an occupational category not clearly indicating to be typical for graduate employment actually perceive a link between study and employment. The findings, if compared with results of surveys of the 1980s, also do not suggest a growth of the proportion of graduates considering themselves as wrongly trained or over-educated.

Finally, graduates had been asked to state the extent to which their work situation about four years after graduation meets the expectations they had at the time of their first enrolment. As Table 6 shows, 7 percent of the graduates consider the work situation much worse than expected and 15 percent somewhat wore than expected. On the whole, these proportions could be expected on the basis of the responses to the prior four questions.

\section{DIFFERENCES BETWEEN COUNTRIES}

About half of the graduates surveyed state that they use the knowledge and skills acquired in their course of study to a high extent in performing their work tasks (see Table 1). This is stated by almost three quarters of the Norwegian and more than two-thirds of the Finnish graduates. In contrast, as already noted, 21 percent perceive little or no use, among them almost half of the Japanese (47\%) and more than one third of the French graduates (36\%).

A more open link between the field of study and the area of employment and work is viewed by about half of the graduates (see Table 2). 38 percent state that some other fields of study could have prepared for the employment and work area as well, and 11 percent believe that the specific field is not relevant for the area of employment and work, i.e. that various other fields could be suitable for their employment and work as well. These views are most frequently held by graduates in Japan (63\%), and Netherlands (62\%) and France (59\%). 
Table 1. Use of Knowledge and Skills Acquired in Reference Study as Perceived by Graduates, by Country (percent and arithmetic mean of graduates employed about four years after graduation)

\begin{tabular}{lllllllllllllll}
\hline & \multicolumn{11}{c|}{ Country } & \multicolumn{11}{c}{ Tota } \\
\hline & IT & ES & FR & AT & DE & NL & UK & FI & SE & NO & CZ & EUR & JP & \\
\hline $\begin{array}{l}\text { To a very high } \\
\text { extent }\end{array}$ & 19 & 21 & 6 & 25 & 14 & 12 & 23 & 35 & 30 & 36 & 23 & 22 & 9 & 21 \\
2 & 30 & 27 & 22 & 30 & 29 & 39 & 27 & 34 & 32 & 38 & 31 & 31 & 13 & 29 \\
3 & 30 & 27 & 35 & 28 & 34 & 33 & 26 & 19 & 26 & 21 & 30 & 28 & 30 & 28 \\
4 & 15 & 19 & 28 & 14 & 20 & 14 & 17 & 10 & 11 & 5 & 13 & 15 & 31 & 16 \\
5 Not at all & 6 & 6 & 8 & 3 & 3 & 2 & 8 & 1 & 1 & 0 & 2 & 4 & 16 & 5 \\
\hline Total & 100 & 100 & 100 & 100 & 100 & 100 & 100 & 100 & 100 & 100 & 100 & 100 & 100 & 100 \\
Count (n) & 2550 & 2166 & 2197 & 2081 & 3239 & 2914 & 3133 & 2455 & 2415 & 3116 & 2628 & 28893 & 2927 & 31821 \\
\hline Arithmetic mean & 2.6 & 2.6 & 3.1 & 2.4 & 2.7 & 2.5 & 2.6 & 2.1 & 2.2 & 1.9 & 2.4 & 2.5 & 3.3 & 2.5 \\
\hline
\end{tabular}

Question F1: If you take into consideration your current work tasks altogether: To what extent do you use the knowledge and skills acquired in the course of study (you graduated from 1994 or 1995)?

Scale of responses from 1 = "To a very high extent" to 5 = "Not at all".

Table 2. Relationship Between Field of Study and Area of Work as Perceived by Graduates, by Country (percent of graduates employed about four years after graduation; multiple responses)

\begin{tabular}{|c|c|c|c|c|c|c|c|c|c|c|c|c|c|c|}
\hline & \multicolumn{13}{|c|}{ Country } & \multirow[t]{2}{*}{ Total } \\
\hline & IT & ES & FR & $\mathrm{AT}$ & DE & FI & SE & NO & CZ & EUR & JP & NL & UK & \\
\hline $\begin{array}{l}\text { My field of study is the } \\
\text { only possible/by far the } \\
\text { best field }\end{array}$ & 51 & 39 & 20 & 47 & 40 & 28 & 37 & 54 & 46 & 51 & 27 & 39 & 23 & 38 \\
\hline $\begin{array}{l}\text { Some other fields could } \\
\text { prepare for the area of } \\
\text { work as well }\end{array}$ & 31 & 40 & 48 & 26 & 39 & 52 & 35 & 31 & 33 & 43 & 50 & 40 & 25 & 38 \\
\hline $\begin{array}{l}\text { Another field would } \\
\text { have been more useful }\end{array}$ & 7 & 10 & 12 & 6 & 8 & 9 & 12 & 7 & 7 & 3 & 13 & 9 & 10 & 9 \\
\hline $\begin{array}{l}\text { The field of study does } \\
\text { not matter very much }\end{array}$ & 6 & 6 & 11 & 10 & 10 & 10 & 22 & 5 & 3 & 3 & 6 & 9 & 28 & 11 \\
\hline $\begin{array}{l}\text { Higher education studies } \\
\text { are not at all related to } \\
\text { my area of work }\end{array}$ & 8 & 5 & 15 & 11 & 8 & 3 & 18 & 2 & 0 & 0 & 4 & 7 & 14 & 8 \\
\hline Others & 1 & 0 & 1 & 1 & 3 & 0 & 3 & 1 & 3 & 1 & 1 & 1 & 0 & 1 \\
\hline Total & 105 & 100 & 107 & 100 & 108 & 102 & 126 & 100 & 192 & 100 & 100 & 105 & 100 & 105 \\
\hline Count (n) & 2534 & 2157 & 2192 & 2076 & 3210 & 2915 & 3076 & 2442 & 2634 & 3109 & 2628 & 26339 & 2984 & 29323 \\
\hline
\end{tabular}

Question F2: How would you characterise the relationship between your field of study and your area of work?

Finally, 17 percent perceive a mismatch been education and employment, either in terms of another field of study being more useful (9\%) or no higher education studies being needed at all (8\%) for the area of work (see Table 3). These two categories were most frequently named by those graduating in the United Kingdom (30\%), France (27\%) and Japan (24\%).

Altogether, 38 percent of the graduates employed state that their field of study is the only one possible or by far the best one for their area of work. This perception is most pronounced, as Table 2 shows, among graduates of the Nordic countries, Italy and Austria.

Two-thirds of the graduates consider their level of degree as most appropriate for their employment and work. As Table 3 shows, the highest proportions of graduates

sharing this view are found in the Nordic countries, the Czech Republic and the Netherlands.

12 percent come to the conclusion, as Table 3 shows as well, that their employment and work require a higher level of study. Among those graduating in France (21\%) and the United Kingdom (16\%), this was most frequently stated - i.e. among countries in which not only the proportions of those surveyed is high who have graduated from a three-year study programme, but also a relatively high percentage of graduates continued their study beyond a three-year programme. 
Table 3. Appropriateness of Level of Course of Study and Degree for Employment and Work, by Country (percent of graduates employed about four years after graduation)

\begin{tabular}{|c|c|c|c|c|c|c|c|c|c|c|c|c|c|c|}
\hline & \multicolumn{13}{|c|}{ Country } & \multirow[t]{2}{*}{ Total } \\
\hline & IT & ES & FR & AT & $\mathrm{DE}$ & FI & $\mathrm{SE}$ & NO & $\mathrm{CZ}$ & EUR & JP & NL & UK & \\
\hline $\begin{array}{l}\text { A higher level than the } \\
\text { one I graduated from }\end{array}$ & 11 & 15 & 21 & 7 & 4 & 11 & 16 & 9 & 12 & 15 & 11 & 12 & 10 & 12 \\
\hline The same level & 58 & 55 & 45 & 67 & 68 & 73 & 60 & 78 & 78 & 76 & 74 & 67 & 55 & 66 \\
\hline $\begin{array}{l}\text { A lower level of } \\
\text { higher/tertiary } \\
\text { education }\end{array}$ & 14 & 11 & 24 & 7 & 19 & 9 & 15 & 9 & 7 & 7 & 5 & 12 & 18 & 12 \\
\hline $\begin{array}{l}\text { No higher/tertiary } \\
\text { education at all }\end{array}$ & 12 & 18 & 7 & 12 & 6 & 7 & 7 & 3 & 2 & 1 & 8 & 7 & 12 & 8 \\
\hline Other & 4 & 1 & 3 & 6 & 3 & 0 & 2 & 1 & 1 & 1 & 1 & 2 & 5 & 2 \\
\hline Total & 100 & 100 & 100 & 100 & 100 & 100 & 100 & 100 & 100 & 100 & 100 & 100 & 100 & 100 \\
\hline Count (n) & 2500 & 2153 & 2160 & 2040 & 3196 & 2910 & 3083 & 2415 & 2397 & 3087 & 2629 & 28569 & 2962 & 31530 \\
\hline
\end{tabular}

Question F3b: What is the most appropriate level of course of study/degree for your employment and work in comparison to that which you graduated from in 1994 or 1995 ?

The proportion of those stating that a lower level of higher education or tertiary education was sufficient or that no higher education or tertiary education was needed at all was highest in France (31\%), Japan (30\%) and Spain (29\%). In the case of Spain, the item "no higher education at all" was chosen by even 18 percent of the graduates as compared to 1-12 percent in other countries.

In response to the question whether they consider altogether, i.e. in taking into account both the substantive and the status dimensions, their employment and work as appropriate to their level of education, about one third state "completely appropriate". A further third consider the link predominantly appropriate, and about one fifth choose a scale point in the centre between "completely appropriate" and "not all appropriate”. Employment and work are rated hardly or not at all appropriate by 13 percent of graduates employed, as already stated above. Table 4 shows that the most favourable ratings were made by Norwegian, Czech and Finnish graduates (this question was not addressed to the Swedish graduates). In contrast, one fifth of more of the graduates in Italy, France and Japan view their employment and work as predominantly or altogether inappropriate.

Table 4. Appropriateness of Employment and Work to the Level of Education as Perceived by Graduates, by Country (percent and mean of graduates employed about four years after graduation)

\begin{tabular}{|c|c|c|c|c|c|c|c|c|c|c|c|c|c|c|}
\hline & \multicolumn{13}{|c|}{ Country } & \multirow[t]{2}{*}{ Total } \\
\hline & IT & ES & FR & AT & DE & FI & SE & NO & $\mathrm{CZ}$ & EUR & JP & NL & UK & \\
\hline $\begin{array}{l}1 \text { Completely } \\
\text { appropriate }\end{array}$ & 19 & 30 & 30 & 28 & 22 & 30 & 40 & 46 & $\mathrm{~m}$ & 55 & 56 & 36 & 12 & 33 \\
\hline 2 & 29 & 34 & 31 & 37 & 39 & 45 & 28 & 36 & $\mathrm{~m}$ & 32 & 27 & 34 & 31 & 34 \\
\hline 3 & 30 & 20 & 18 & 22 & 24 & 17 & 14 & 11 & $\mathrm{~m}$ & 10 & 10 & 17 & 37 & 19 \\
\hline 4 & 16 & 11 & 13 & 8 & 11 & 6 & 11 & 5 & $\mathrm{~m}$ & 3 & 5 & 9 & 14 & 9 \\
\hline $\begin{array}{l}5 \text { Not at all } \\
\text { appropriate }\end{array}$ & 6 & 5 & 8 & 4 & 4 & 2 & 7 & 2 & $\mathrm{~m}$ & 1 & 1 & 4 & 6 & 4 \\
\hline Total & 100 & 100 & 100 & 100 & 100 & 100 & 100 & 100 & $\mathrm{~m}$ & 100 & 100 & 100 & 100 & 100 \\
\hline Count (n) & 2535 & 2161 & 2183 & 2080 & 3228 & 2914 & 3084 & 2448 & $\mathrm{~m}$ & 3115 & 2624 & 26372 & 2984 & 29355 \\
\hline Arithmetic mea & 2.6 & 2.3 & 2.4 & 2.2 & 2.4 & 2.0 & 2.2 & 1.8 & $\mathrm{~m}$ & 1.6 & 1.7 & 2.1 & 2.7 & 2.2 \\
\hline
\end{tabular}

Question F3a: If you consider all dimensions of your employment and work (status, position, income, work tasks, etc.: To what extent is your employment and work appropriate to your level of education? Scale of responses from 1 = "Completely appropriate" to $5=$ "Not at all appropriate".

Finally, graduates were asked to state how their current work situation meets the expectations they had at the beginning of their study. We did not consider in this analysis those who responded "I did not have any expectations”. It is interesting to note that a relatively high proportion of graduates (41\%) find their current work situation above what they had expected upon enrolment (see Table 5). More than two-thirds of the graduates in Norway (69\%) and half of graduates in Finland (49\%) share this view. In addition, more than one third consider there current work as meeting their prior 
expectations.

In contrast, as already stated, only 22 percent of the graduates employed think that their current situation is worse than expected. This is true for about half of the graduates in Japan (51\%), more than one third in Spain (37\%) and almost one third in Italy (30\%).

Table 5. Current Work Situation Meeting the Graduates’ Expectations at the Time of Enrolment, by Country (percent and arithmetic means of graduates employed about four years after graduation)

\begin{tabular}{|c|c|c|c|c|c|c|c|c|c|c|c|c|c|c|}
\hline & \multicolumn{13}{|c|}{ Country } & \multirow[t]{2}{*}{ Total } \\
\hline & IT & ES & FR & AT & $\mathrm{DE}$ & FI & SE & NO & $\mathrm{CZ}$ & EUR & JP & NL & UK & \\
\hline $\begin{array}{l}1 \text { Much better } \\
\text { than expected }\end{array}$ & 6 & 10 & 8 & 12 & 8 & 7 & 8 & 18 & 7 & 25 & 13 & 11 & 8 & 11 \\
\hline 2 & 26 & 15 & 31 & 33 & 33 & 35 & 29 & 31 & 33 & 44 & 28 & 31 & 15 & 30 \\
\hline 3 & 38 & 38 & 37 & 41 & 42 & 48 & 39 & 36 & 37 & 24 & 44 & 39 & 26 & 37 \\
\hline 4 & 15 & 29 & 12 & 9 & 12 & 8 & 17 & 10 & 16 & 5 & 13 & 13 & 33 & 15 \\
\hline $\begin{array}{l}5 \text { Much worse } \\
\text { than expected }\end{array}$ & 15 & 8 & 11 & 4 & 5 & 2 & 8 & 5 & 6 & 2 & 2 & 6 & 18 & 7 \\
\hline Total & 100 & 100 & 100 & 100 & 100 & 100 & 100 & 100 & 100 & 100 & 100 & 100 & 100 & 100 \\
\hline Count (n) & 2327 & 2065 & 1882 & 2059 & 2941 & 2575 & 2739 & 2439 & 2134 & 2923 & 2466 & 26549 & 2394 & 28943 \\
\hline Arithmetic mean & 3.1 & 3.1 & 2.9 & 2.6 & 2.7 & 2.6 & 2.9 & 2.5 & 2.8 & 2.2 & 2.6 & 2.7 & 3.4 & 2.8 \\
\hline
\end{tabular}

Question F5: Taking all aspects into account, to what extent does your current work situation meet the expectations you had when you started your study?

Scale of responses from 1 = "Much better than expected" to $5=$ "Much worse than expected".

In looking at the responses to all the five questions raised regarding the links between the substance of study and work as well as regarding the level of education and employment and work, we note that Norwegian graduates consistently state the highest degree of appropriateness. Actually, a very high proportion of the Norwegian graduates surveyed graduated from short-cycle programmes and are employed in associate professional occupations. This obviously is not a reason for most of these graduates to cast doubts as regards the appropriateness of work.

Graduates from the other Nordic countries come next in considering their employment and work as appropriate to their level of education, closely followed by the Netherlands and the Czech Republic. Austria and Germany are mostly close to the average of the countries surveyed in those respects.

In contrast, Japanese graduates perceive most frequently an inappropriate employment and work situation, followed by France. Also, the ratings of graduates in the United Kingdom, Italy and Spain tend to be below average.

This rank order of countries not related to that of the quotas of graduates of the respective age group. Thus, high levels of inappropriate employment cannot be explained by a low selectivity of the higher education system. The rank order of countries according to the frequency, however, is moderately correlated to a rank order of proportions in occupation groups usually considered inappropriate for graduates, i.e. clerks, sales persons, workers and other, where the highest quota is reported in Japan, followed by Spain. This underscores a certain link between objective and subjective criteria of appropriateness of employment. However, French and Italian graduates consider themselves experiencing inappropriate employment more often compared to graduates from other countries than one could expect on the basis of the occupational ranks.

Obviously, another factor comes more strongly into play: graduates in "professional" (including "associate professional”) occupations as well as graduates in the public sector are more likely to consider themselves being in an appropriate position than graduates in the private sector. It cannot be established whether this is due to a to a more favourable view of many graduates regarding publicsector employment, whether this primarily reflects a clearer link of career ladders to entry qualifications in the public sector or whether the private sector is clearly more open than the public sector for employment of graduates below the status bottom line and with less substantive links between education and employment than considered appropriate.

\section{DIFFERENCES BETWEEN FIELDS OF STUDY}

In response to the question regarding the extent to which study was useful to prepare for the job about four years after graduation, graduates from medical fields perceive the closest substantive link between 
study and work, followed by graduates from education. In contrast, the link is viewed less closely as on average by graduates from humanities and natural sciences.

The responses are similar to another question as regards how the field of study is linked to the area of work. Again, graduates from medicine consider most frequently their field of study as the only possible or by far the best field (76\%). This proportion reaches 94 percent in Sweden, 89 percent in Italy and Austria as well as 87 percent in Germany and is the lowest in Norway (68\%), as Table 6 shows.

A relatively close link between the field of study and the area of work is also perceived by graduates from education and law: 54 percent and 56 percent respectively of their graduates think their field is the only one possible and by far the best. In law, this is most often true in Germany (76\%), Sweden (72\%) and Italy (71\%). In contrast, the links are viewed as lowest by French (35\%) and Dutch graduates (42\%), where the job prospects of law graduates seem to be more diversified. About three quarters of the Finnish and Swedish graduates from education consider their field of study is the only possible or by far the best. This is also the case among more than 60 percent of British and Norwegian education graduates; in these countries, the demand for teachers and the supply of teachers seems to match more closely than in the other countries surveyed. In contrast, the respective proportion is only about 40 percent in Spain, Germany, and Japan and even lower in the Czech Republic.

Table 6. Relationship Between Field of Study and Area of Work as Perceived, by Graduates, by Field of Study (percent of graduates employed about four years after graduation; multiple responses)

\begin{tabular}{|c|c|c|c|c|c|c|c|c|c|}
\hline & \multicolumn{8}{|c|}{ Field of study } & \multirow[t]{2}{*}{ Total } \\
\hline & Educ & Hum. & Soc. & Law. & Nat. & Math. & Eng. & Med. & \\
\hline $\begin{array}{l}\text { My field of study is the only } \\
\text { possible/by far the best field }\end{array}$ & 54 & 33 & 26 & 56 & 29 & 38 & 32 & 76 & 39 \\
\hline $\begin{array}{l}\text { Some other fields could } \\
\text { prepare for the area of work as } \\
\text { well }\end{array}$ & 29 & 30 & 46 & 27 & 40 & 48 & 46 & 20 & 38 \\
\hline $\begin{array}{l}\text { Another field would have been } \\
\text { more useful }\end{array}$ & 6 & 11 & 9 & 6 & 14 & 7 & 10 & 2 & 8 \\
\hline $\begin{array}{l}\text { The field of study does not } \\
\text { matter very much }\end{array}$ & 6 & 17 & 14 & 8 & 12 & 6 & 9 & 2 & 10 \\
\hline $\begin{array}{l}\text { Higher education studies are } \\
\text { not at all related to my area of } \\
\text { work }\end{array}$ & 4 & 15 & 8 & 6 & 11 & 5 & 4 & 1 & 7 \\
\hline Others & 2 & 2 & 1 & 1 & 1 & 1 & 1 & 1 & 1 \\
\hline Total & 102 & 109 & 104 & 104 & 107 & 105 & 103 & 101 & 104 \\
\hline Count (n) & 3039 & 3762 & 9364 & 2322 & 1827 & 1288 & 6552 & 3012 & 31165 \\
\hline
\end{tabular}

Question F2: How would you characterise the relationship between your field of study and your area of work?

The proportion of graduates who think that their field of study is the only possible or by far the best field is lower in other fields of study. We cannot establish the extent to which this is due to a high specialisation of fields where neighbour fields often can prepare as well, to work tasks cutting across fields or to a difficult labour market situation. But, again we note exceptions. A close link between field of study and area of work is felt about one and a half times as often by Spanish and Finnish graduates in mathematics as the average of graduates from mathematics, and similarly relatively often Finnish, Italian and Norwegian graduates from natural sciences.

The two other items signalling a loose substantive link between study and work and partly also a low position, i.e. "The field of study does not matter very much" and "Higher education studies are not at all related to my area of work", are most often named by graduates from the humanities $(17 \%$ and $15 \%$ respectively). This is most often the case for humanities graduates in the United Kingdom and in Austria, followed by humanities graduates in Italy, France and Japan. The situation is somewhat better for graduates from the social sciences (14\% and $8 \%$ respectively), with most difficulties observed in the United Kingdom (41\%) and in Japan (41\%).

Asked which level of education is most appropriate, again the graduates from medicine perceive most frequently a level of employment and work which at least fits their level of education. As Table 7 shows, 93 percent consider the same or a higher level of education as most appropriate for their level of study and degree. The respective ratio was 83 percent for education, mathematics and engineering, around 75 percent in law, natural sciences and social sciences, and eventually 63 percent in the 
humanities.

Table 7. Appropriateness of Level of Course of Study and Degree for Employment and Work, by Field of Study (percent of graduates employed about four years after graduation)

\begin{tabular}{|l|c|c|c|c|c|c|c|c|}
\hline & \multicolumn{9}{|c|}{ Field of study } \\
\hline & Educ. & Hum. & Soc. & Law & Nat. & Math. & Eng. & Med. \\
\hline $\begin{array}{l}\text { A higher level than the one I graduated } \\
\text { from }\end{array}$ & 11 & 11 & 10 & 13 & 15 & 14 & 1019 & 12 \\
\hline The same level & 72 & 53 & 63 & 66 & 62 & 69 & 7274 \\
\hline $\begin{array}{l}\text { A lower level of higher / tertiary } \\
\text { education }\end{array}$ & 8 & 19 & 14 & 12 & 13 & 12 & 114 & 66 \\
\hline No higher/tertiary education at all & 7 & 14 & 10 & 7 & 7 & 4 & 62 & 21 \\
\hline Other & 2 & 3 & 3 & 3 & 2 & 1 & 2 \\
\hline Total & 100 & 100 & 100 & 100 & 100 & 100 & 100100 \\
\hline Count (n) & 3039 & 3742 & 9306 & 2293 & 1805 & 1280 & 6514299330972 & 100 \\
\hline
\end{tabular}

Question F3b: What is the most appropriate level of course of study/degree for your employment and work in comparison to that which you graduated from in 1994 or 1995?

Asked to consider all dimensions of employment and work together,

- 81 percent of the graduates from medicine,

- $\quad$ about three quarters from mathematics (76\%) and education (75\%),

- slightly more than two-thirds from engineering (70\%), law (68\%) and natural sciences $(67 \%)$,

- somewhat fewer in social sciences (62\%), and

- $\quad$ again the lowest proportion of graduates from humanities (55\%)

state that their employment and work is completely or predominantly appropriate

for their level of education. Thus, we note that across all the questions and their different emphasis on the substantive and status relationship between higher education on the one hand and on the other hand employment an work, the graduates from medicine observe the closest links. Education is consistently above average, but not always on the second place. Finally, graduates from the humanities note least frequently such a close link.

The differences according to field of study are consistently smaller than the differences according to country, but by no means negligeable. In looking at the differences between countries within single fields of study, we already demonstrated examples of variation with respect to the link between field of study and the area of work. Similar differences might be observed with respect to the level of educational programme and degree and the level of employment and work. A lower level of educational programme and degree is relatively often considered appropriate by

- German graduates from medicine,

- Japanese graduates from engineering,

- Italian graduates from mathematics,

- Spanish, Italian and German graduates from education,

- Italian, French and German graduates from the natural sciences,

- Spanish, French and Japanese graduates from law,

- Italian, Spanish, French and Japanese graduates from the social sciences, and

- Italian, Austrian and Japanese graduates from the humanities.

Naturally, the names of countries show up most frequently, which has already been identified above as those where a relatively high proportion of graduates

considering employment and work as not completely adequate. The most striking finding in looking at the combination of fields of study and country is the high proportion of Austrian graduates from humanities (36\%) who believe that no higher education was required for their job. One has to bear in mind, though, that colleges

for training elementary school teachers, social workers, etc. in Austria are viewed as being outside higher education, while in all other countries they are considered part of higher education.

\section{REASONS FOR TAKING A JOB HARDLY LINKED TO STUDY}

Graduates not considering their employment and work altogether or predominantly appropriate as compared to their level of study and degree we asked to state why they have accepted such a position. As Table 8 suggests, most graduates had several reasons for this decision. 
Five items are most frequently quoted:

- " "my current job is more interesting” (13\% of all employed graduates);

- "I have not yet been able to find a job more appropriate” (11\%);

- "In doing this job, I have better career prospects” (10\%);

- "My current job enables me to work in a locality, which I prefer” (10\%);

- "My current job offers me more security” (9\%).

Only about one third of the graduates being in a job not clearly or even not at all appropriate, i.e. less than 15 percent seem to be in such a job involuntarily. The other about two-thirds who do not consider their job as fully or predominantly adequate accept such a position, because they view their job as attractive in some respects (interesting assignment, promotion prospects, high job security, etc.) or because they took their job in order to accommodate family needs and regional preferences more easily.

Among all the reasons given, those stated by the Spanish, Italian and French graduates most frequently refer to difficulties linked to employment opportunities. In contrast, the Japanese and Czech graduates most frequently state other reasons for excepting such a position.

Table 8. Reasons for Taking a Job Hardly Linked to Study, by Country (percent of graduates employed about four years after graduation; multiple responses)

\begin{tabular}{|c|c|c|c|c|c|c|c|c|c|c|c|c|c|c|}
\hline & \multicolumn{13}{|c|}{ Country } & \multirow[t]{2}{*}{ Tota } \\
\hline & IT & ES & FR & $\mathrm{AT}$ & $\mathrm{DE}$ & FI & $\mathrm{SE}$ & NO & $\mathrm{CZ}$ & EUR & $\mathrm{JP}$ & NL & UK & \\
\hline $\begin{array}{l}\text { I have not (yet) been able to find } \\
\text { a job more appropriate }\end{array}$ & 21 & 15 & 16 & 8 & 12 & 7 & 15 & 7 & 10 & 5 & 11 & 11 & 12 & 11 \\
\hline $\begin{array}{l}\text { In doing this job I have better } \\
\text { career prospects }\end{array}$ & 9 & 8 & 12 & 8 & 11 & 9 & 14 & 7 & 8 & 5 & 19 & 10 & 11 & 10 \\
\hline $\begin{array}{l}\text { I prefer an occupation which is } \\
\text { not closely connected to my } \\
\text { studies }\end{array}$ & 2 & 1 & 4 & 3 & 3 & 3 & 5 & 11 & 2 & 1 & 6 & 4 & 7 & 4 \\
\hline $\begin{array}{l}\text { I was promoted to a position less } \\
\text { linked to my studies than my } \\
\text { previous position(s) }\end{array}$ & 0 & 0 & 1 & 1 & 1 & 1 & 2 & 1 & 2 & 1 & 8 & 2 & 0 & 2 \\
\hline $\begin{array}{l}\text { I can get a higher income in my } \\
\text { current job }\end{array}$ & 4 & 3 & 7 & 6 & 5 & 4 & 12 & 5 & 7 & 4 & 20 & 7 & 7 & 7 \\
\hline $\begin{array}{l}\text { My current job offers me more } \\
\text { security }\end{array}$ & 10 & 8 & 9 & 6 & 8 & 5 & 9 & 8 & 2 & 3 & 20 & 8 & 23 & 9 \\
\hline $\begin{array}{c}\text { My current job is more } \\
\text { interesting }\end{array}$ & 8 & 7 & 12 & 10 & 13 & 12 & 12 & 13 & 12 & 5 & 25 & 12 & 22 & 13 \\
\hline $\begin{array}{l}\text { My current job provides the } \\
\text { opportunity forpart-time/flexible } \\
\text { schedules etc. }\end{array}$ & 11 & 6 & 5 & 9 & 9 & 4 & 5 & 6 & 6 & 4 & 9 & 7 & 4 & 6 \\
\hline $\begin{array}{l}\text { My current job enables me to } \\
\text { work in a locality, which I prefer }\end{array}$ & 6 & 7 & 8 & 8 & 11 & 5 & 11 & 8 & 7 & 6 & 22 & 9 & 20 & 10 \\
\hline $\begin{array}{l}\text { My current job allows me to } \\
\text { take into account family needs }\end{array}$ & 9 & 4 & 5 & 6 & 7 & 2 & 4 & 5 & 5 & 4 & 17 & 6 & 7 & 6 \\
\hline $\begin{array}{l}\text { At the beginning of the career } \\
\text { envisaged I haveto accept work } \\
\text { hardly linked to my study }\end{array}$ & 4 & 5 & 7 & 5 & 5 & 2 & 4 & 8 & 2 & 3 & 12 & 5 & 4 & 5 \\
\hline Other & 3 & 2 & 6 & 5 & 6 & 7 & 6 & 2 & 6 & 2 & 4 & 5 & 11 & 5 \\
\hline Count (n) & 2774 & 2322 & 2512 & 2275 & 3369 & 2983 & 3293 & 2615 & 2594 & 3202 & 2915 & 30853 & 3055 & 33908 \\
\hline
\end{tabular}

Question F4: If you consider your employment and work as hardly appropriate and not linked to your education: why did you take it up? Multiple responses possible.

Finally, across the whole sample, there appears clear gender differences in the reasons. Male graduates are more likely to accept a job hardly linked to study because it gives them better opportunities for career prospects, higher income, and more interesting work. Female graduates, in contrast, either have less choice in their present situation, or they seek more part-time schedules in part for family needs. 
In debates about the extent to which study and subsequent work are linked, two dimensions tend to be addressed, as discussed in the introduction of this chapter. On the one hand, fields of study might be substantially linked closely to certain areas of work. We call this a "high specifity" of a field of study and the opposite situation, i.e. a loose substantive link, a "low specifity" of a field of study. On the other hand, the status of study and employment might be closely linked. Employment and work in occupational areas might be considered to be clearly appropriate for graduates from institutions of higher education; we call these "high level occupations" and correspondingly those "low level occupations" which are not considered clearly as appropriate for graduates.

The analysis undertaken above shows that a distinction of the two dimensions is sound, even if we note that they not always clearly distinct in the public debate and in the minds of the graduates. Therefore, we have created a typology of the inter- relationships between these two dimensions, whereby we take the statement "My field is the best/the only one possible" (see the first lines of Table 2 and Table 6) as the indicator of "high specifity" vs. "low specifity" and the responses "A higher level than the one I graduated from" and "The same level" to the question "What is the most appropriate level of course of study for your job?" (see the first and second lines of Table 3 and 8.7) as the indicator of "high level occupations” vs. "low level occupations".

Certainly, graduates can consider themselves as most privileged in tune with the values of a professional and meritocratic society, if their employment and work is characterized both by a high specificy and a high level. As Figure 1 shows, this applied to graduates from medicine are in all countries and for graduates from law in most countries.

On the other hand, graduates with low specifity and low occupational level are certainly in the worst situation. According to the indicators chosen, this holds true for graduates in the humanities and social sciences in all countries surveyed.

Graduates from fields that lead to high positions, but have low specifity can be viewed as being in a relatively good labour market situation - almost as well as the first group named above. Even if they do not have the privileges of the highest-level professional status, they obviously come from a field which ensures a broad range of different domains and thus allows them to diversify their career and, in addition, make them able to resist the fluctuations in the labour market. This seems to hold true for graduates in engineering in almost all countries and from the natural sciences in most countries.

Graduates from fields with high specifity and leading to low level occupations can probably considered to be in a difficult labour market situation. Their study might be narrow, thus limiting the graduations' career opportunities. According to Figure 1, this is only the case for graduates from a single or at most two countries each within the majority of fields of study.

Figure 17. Specificity and Level of Occupation, by Field of Study and Country

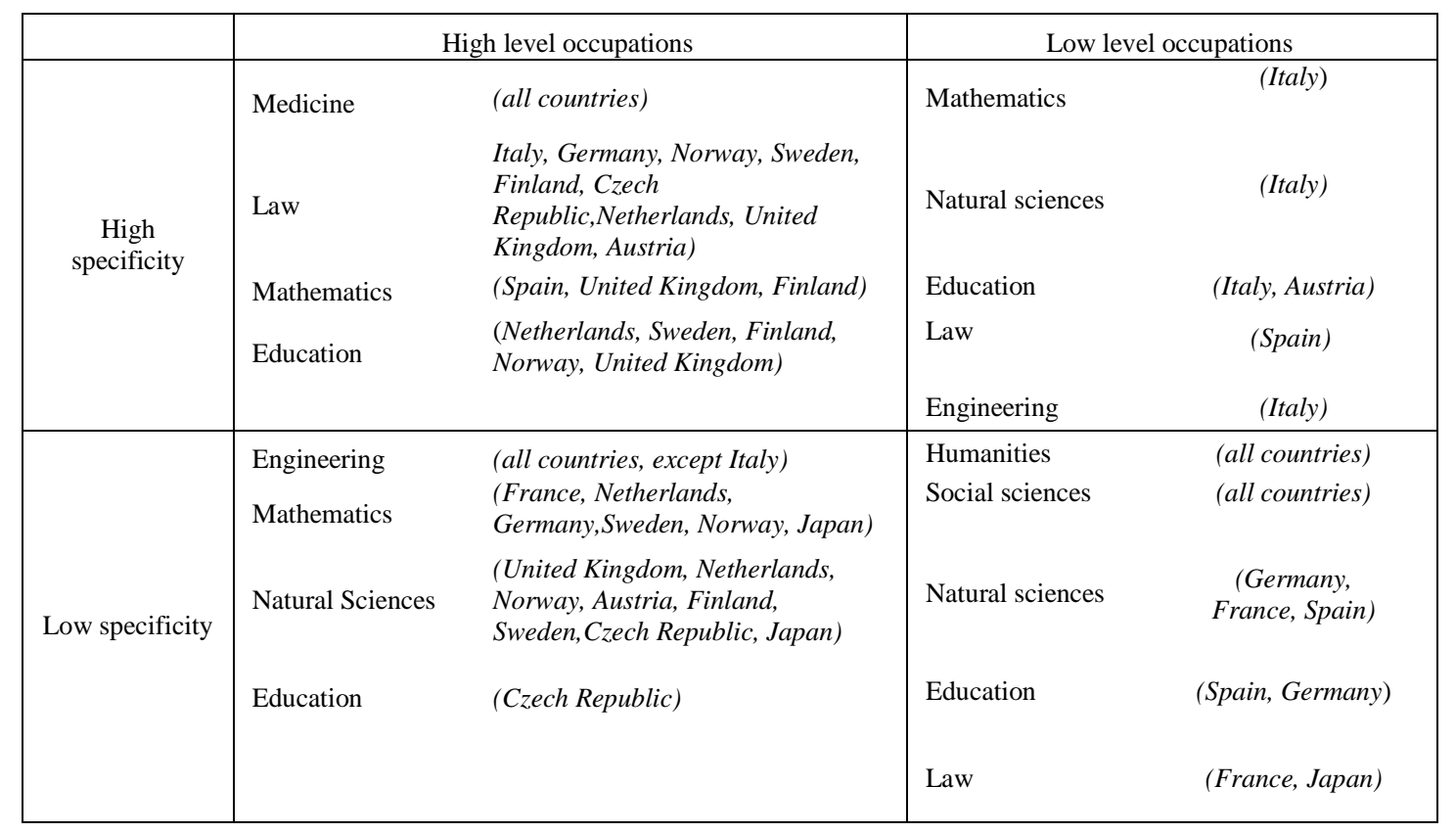


Two fields of study are most widely spread across the four types: education and mathematics. For example, graduates from education note a high level of specifity and a high occupational level in five countries (the Netherlands, Sweden, Finland, Norway, and the United Kingdom), they appear to be in a non specific and highly qualified job in the Czech Republic, in a specific and low-position situation in Italy and Austria, and finally in a non-specific low-level position in Spain and Germany. Certainly, specific conditions of teacher training, the demand and supply on the market as well as work characteristics and the status of the teacher within each country play a role.

Across fields of study, Italy represents a very peculiar country, compared to the others. Four fields are considered by their graduates as specific but lowly qualified. This is due to the fact that phenomena of "over-qualification" seem to be more frequent on the labour market for graduates in Italy than in almost all the other countries surveyed.

In interpreting the findings reported in this sector, we have to bear in mind, though, that the groups of field of study presented are in some cases heterogeneous. Notably, many graduates of some of the social science fields are in high level positions. Also, we note that a considerable proportion of graduates state a substantial utilisation on the job of their knowledge and competences acquired in the course of study. Thus, the proportion of graduates perceiving a certain substantive link between higher education and subsequent work is higher than Figure 1 might suggest.

\section{SUMMARY}

In analysing the links between study and subsequent employment and work not only according to occupational categories and income, but also with the help of the graduates' perceptions and judgements, we are suggested to specify and partly modify the picture. First, the graduates from medical fields note on average the closest links between study and work about fours years after graduation, even though their average income at that time is not very high. Obviously, many graduates of this field are very confident about four years after graduation that they can expect a promising career.

There are many cases where high income, a high-level position, a perception of being in a high-level occupation and a close link between study and job tasks coincide. We also note, however, that many graduates consider themselves being in an appropriate position and having the opportunity of utilising their knowledge, even if they do not consider their field of study as clearly the best preparation for their area of work: this is often true for graduates from engineering and natural sciences. On the other hand, we note a perception of a close substantive and status link between study and work, even if the jobs do not yield a very high income: this is true, for example, for most graduates from teacher training who become teachers. Altogether, the findings suggests that many graduates perceiving a clear substantive link between study and work are inclined to rate their position as adequate for their level of education, even if the income is not above average for graduates. This is not only true for graduates from education, but also for many other graduates getting employed in the public sector.

Finally, graduates from humanities seem to be least privileged among graduates all the respect discussed. This holds true both for "objective" and "subjective" indicators.

Altogether, the differences by country more impressive than those by field of study as far as the perceived links between study and work are concerned. Across the various measures of substantive and status links, graduates from Norway consider their employment and work most often as appropriate to their level of education and to their knowledge, followed by graduates from other Nordic countries and thereafter graduates of the Netherlands and the Czech Republic. Austria and Germany represent very much the average in those respects. In contrast, Japanese graduates perceived most frequently an inappropriate employment and work, followed by graduates from institutions of higher education in France. Also, the ratings of the graduates in the United Kingdom, Italy and Spain tend to be below average. Various factors seem to play a role, among them most strikingly a large segment of public sector seems to reinforce the perection of an appropriate relationship between higher education and the world of work.

\section{REFERENCES}

Allen, J., van Eijs, P., Huijgen, T., Ramaekers, G., van der Velden, R., Verbeek, F. and R. de Vries (2001). WOMonitor 2000. De arbeidsmarktpositie van afgestudeerden van de Nederlandse universiteiten. Utrecht: VSNU.

Arnesen, C.Å. (2000). "Higher education and graduate employment in Norway." European Journal of Education 35, 221-228.

Brennan, J. et al. (1993). Students Courses and Jobs: the Relationship between Higher Education and the Labour Market. London: Jessica Kingsley Publishers.

Brennan, J. and P.A. McGeevor (1988). Graduates at Work: Degree Courses and the Labour Market. London: Jessica Kingsley Publishers. 
Kellermann, P. in cooperation with L. Lassnig (1996). Hochschulabsolvent/inn/en und Beschäftigung '96 (Forschungsbericht). Klagenfurt.

Schomburg, H. and U. Teichler (1993). “Does the Programme Matter?” Higher Education in Europe 18(2), 37-58.

Teichler, U. (1988) "Higher Education and Work in Europe." In Smart, J.C. (ed.). Higher Education: Handbook of Theory and Research, vol. IV. New York: Agathon Press, pp. 109-182.

Teichler, U. and M. Buttgereit (eds.) (1992). Hochschulabsolventen im Beruf. Bad Honnef: K.H. Bock. 